\title{
Acute Ischemic Stroke in Patient with Coronavirus Disease
} Koronavirüs Hastasında Akut İskemik İnme

\author{
University of Health Sciences Turkey, Konya Training and Research Hospital, Clinic of Neurology, Konya, Turkey
}

Keywords: Ischemic stroke, thrombosis, coronavirus, COVID-19

Anahtar Kelimeler: İskemik inme, tromboz, koronavirüs, COVID-19

Dear Editor,

A 89-year-old female patient was admitted to the emergency department with the symptom of impaired consciousness for 3 days. She had a history of chronic renal failure. Her body temperature was $37.9^{\circ} \mathrm{C}$ and her blood pressure was $160 / 100 \mathrm{~mm}$ hemoglobin
$(\mathrm{Hg})$. Diffusion-weighted magnetic resonance imaging showed a focal, hyperintense lesion (cortical-subcortical area in the parietal lobe and precentral gyrus in the left frontal lobe) and apparent diffusion coefficient mapping showed a hypointensity in the same location (Figure 1). Bilateral slow-wave activity was detected with electroencephalography. No hemorrhage was detected in brain

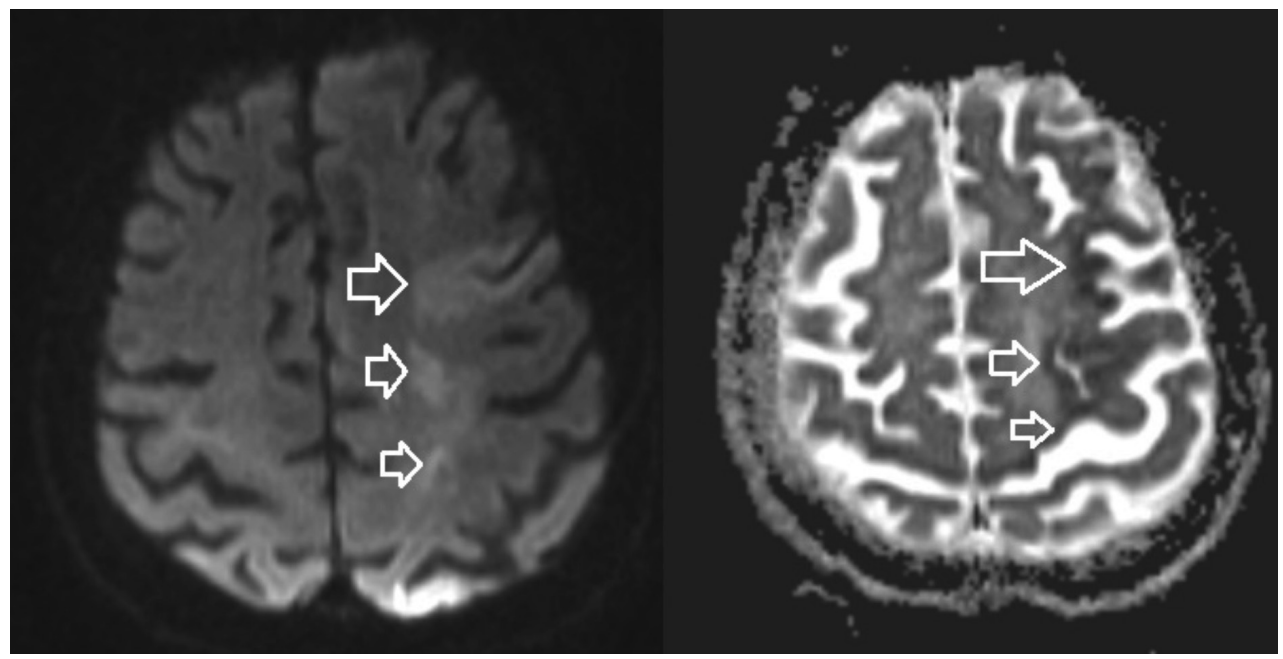

Figure 1. Diffusion-weighted MRI: focal, hyperintense lesion (cortical-subcortical area in the parietal lobe and precentral gyrus in the left frontal lobe); ADC mapping: hypointensity in the same location

MRI: Magnetic resonance imaging, ADC: Apparent diffusion coefficient

Address for Correspondence/Yazışma Adresi: Fettah Eren MD, University of Health Sciences Turkey, Konya Training and Research Hospital, Clinic of Neurology, Konya, Turkey

Phone: +90 3322244007 E-mail: dreren42@hotmail.com ORCID: orcid.org/0000-0001-6834-0827

Received/Geliş Tarihi: 18.05.2020 Accepted/Kabul Tarihi: 29.06.2020

${ }^{\circ}$ Copyright 2020 by Turkish Neurological Society

Turkish Journal of Neurology published by Galenos Publishing House. 
computed tomography (CT). Hyperdense and focal infiltration areas in the lower lobes, and partially in the upper and middle lobes of the lungs were observed in a thorax CT scan (like viral pneumonia) (Figure 2). Laboratory results were $\mathrm{Hg}: 10.8 \mathrm{~g} / \mathrm{dl}$ (normal: 11.9-14.6), platelets: $14410^{3} / \mathrm{mm}^{3}$ (normal: 150-450), white blood cells: $12.87103 / \mathrm{mm}^{3}$ (normal: 4.49-12.68), C-reactive protein $45.2 \mathrm{mg} / \mathrm{l}$ (normal: 0-5), procalcitonin $29.34 \mathrm{ng} / \mathrm{ml}(0-$
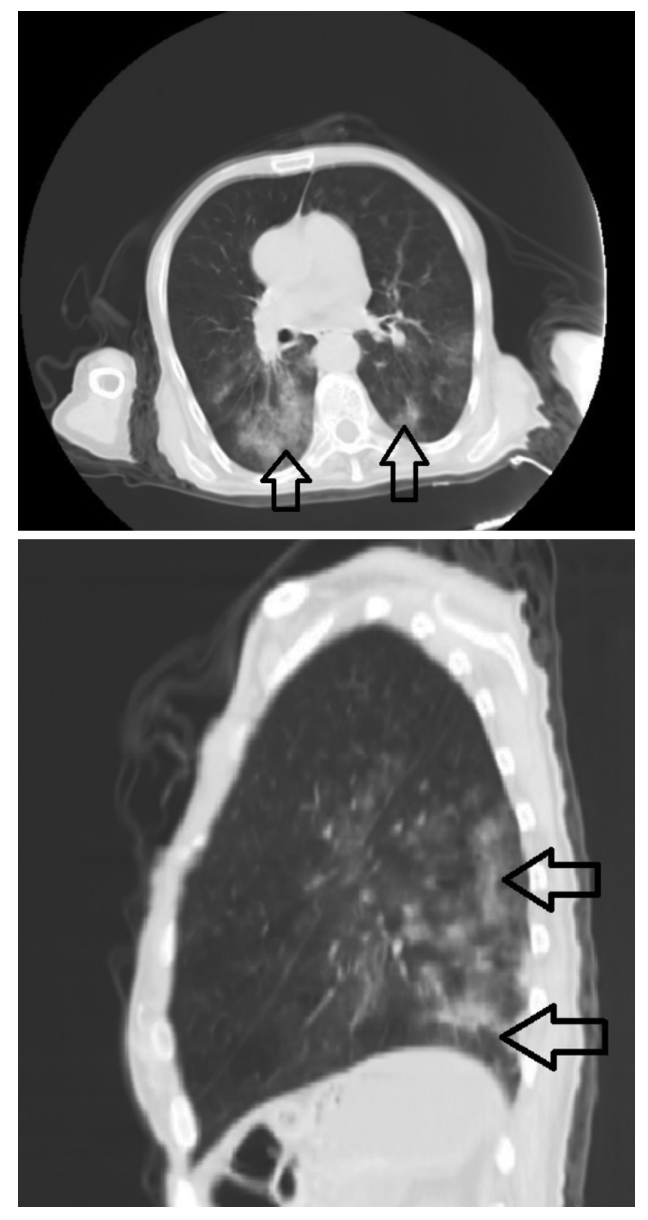

Figure 2. Thorax CT scan: hyperdense and focal infiltration areas in the lower lobes, partially in the upper and middle lobes of lungs (like viral pneumonia)

CT: Computed tomography
0.5 ), urea $179 \mathrm{mg} / \mathrm{dl}$ (normal: 14-43) and creatinine $2.86 \mathrm{mg} / \mathrm{dl}$ (normal: 0.66-1.09). Other blood tests were normal. The patient was intubated in the intensive care unit during the treatment process. The coronavirus disease 19 (COVID-19) test result was positive. Plaquenil, azithromycin, and oseltamivir treatment was started for COVID-19. Informed consent for sharing the patient's details and images for scientific purposes was obtained from the patient's daughter.

COVID-19 is an infectious disease that can cause venous and arterial thromboembolism. This is associated with extensive intravascular coagulation, excessive inflammation, immobilization, and hypoxia $(1,2)$. Although many complications of the disease have been described. Thrombotic complications (especially ischemic stroke) are rarer $(1,2,3)$. Data on the incidence of thromboembolism and ischemic stroke in patients with COVID-19 are insufficient. However, it should be noted that COVID-19 and thromboembolism may be related.

\section{Ethics}

Informed Consent: Informed consent for sharing the patient's details and images for scientific purposes was obtained from the patient's daughter.

Peer-review: Externally peer-reviewed.

\section{Authorship Contributions}

Surgical and Medical Practices: F.E., A.D., Concept: F.E., A.D., Design: F.E., A.D., Data Collection or Processing: F.E., A.D., Analysis or Interpretation: F.E., Literature Search: F.E., A.D., Writing: F.E.

Conflict of Interest: No conflict of interest was declared by the authors.

Financial Disclosure: The authors declared that this study received no financial support.

\section{References}

1. Guan WJ, Ni ZY, Hu Y, et al. Clinical characteristics of coronavirus disease 2019 in China. N Engl J Med 2020;382:1708-1720.

2. Zhou F, Yu T, Du R, et al. Clinical course and risk factors for mortality of adult inpatients with COVID-19 in Wuhan, China: a retrospective cohort study. Lancet 2020;395:1054-1062.

3. Klok FA, Kruip MJHA, Van der Meer NJM, et al. Incidence of thrombotic complications in critically ill ICU patients with COVID-19. Thromb Res 2020;191:145-147. 